Egyptian Journal of Rabbit Science, 27 (2): 447- 461(2017)

\title{
CHANGING FEEDING TIME TO AVOID THE HARMFUL EFFECTS OF HOT SUMMER ON PERFORMANCE OF GROWING NEW ZEALAND WHITE RABBITS
}

\author{
M. F. A. Farghly ${ }^{1}$;h. M. Mahrose ${ }^{2}$ and M. M. Farghaly ${ }^{3}$ \\ ${ }^{1}$ Poultry Prod. Dept., Fac. Agric., Assiut Univ., Assiut 71515, Egypt. \\ ${ }^{2}$ Poultry Dept., Fac. Agric., Zagazig University, Zagazig 44511, Egypt \\ ${ }^{3}$ Animal Prod. Dept., Fac. Agric., Assiut Univ., Assiut 71515, Egypt. \\ Corresponding author: farghly20002000@aun.edu.eg \& ostrichkhalid@zu.edu.eg
}

This experiment was conducted to investigate the effects of feeding times (at morning or afternoon) on productive performance of growing New Zealand White (NZW) rabbits in the hot summer of Assiut, Upper Egypt. Sixty-five male weaned rabbits, six weeks old of age with an average (734.8g ), were reared in batteries and assigned to 4 groups (16 rabbits/each). Rabbits were divided into randomly five experimental groups (13 rabbits per each), during experimental period from 6 to 16 weeks of age. The first group as a control $(C)$, the feed was offered ad libitum daily. While, in the second treated group (T1), rabbits were fed during 10:00 and 16:00 h. The third group (T2) was fed during 16:00 to 22:00 h. The fourth group (T3) was fed during 22:00 to 04:00 $\mathrm{h}$. The fifth group (T4) was fed at 04:00 to 10:00 $\mathrm{h}$ during the experimental periods from 6 tol6 weeks of age.

The results showed that there were significant $(P<0.05)$ differences in body weight (at 12, 14 and 16 weeks of age), body weight gain (during 14-16 and 6-16 weeks of age), feed intake (during 14-16 weeks of age) and feed conversion ratio (during 14-16 and 6-16 weeks of age) among all groups. The rabbits belonging to T3 group had the greatest averages and the lowest feed conversion ratio when compared with the other groups.

The rabbits were fed during 2200 to $0400 h$ showed significantly $(P<0.05)$ the highest percentages of dressed weight as compared with their counterparts. However, rabbits of the control group gave significantly $(P<0.05)$ the lowest average of whole fat percentage in comparison with the other experimental groups. Non-significant differences were found in the other carcass characteristics due to changing feeding time. 
Rabbits of $T 3$ group showed the lowest $(P<0.05)$ values of albumin/ globulin ratio $(A / G)$ and neutrophil/ lymphocytes $(N / L)$ ratio when compared with their counterparts. Glucose concentration was high $(P<0.05)$ in plasma of rabbits of the control group and those fed during 22:00 to 04:00 h. Body temperature of rabbits fed during 22:00 to 04:00 $h$ had the lowest temperature as compared with the other groups. There were non-significant differences in morbidity, mortality and health risk percentages.

Conclusively, it could be concluded from the present results, that changing feeding time in growing rabbits during 22:00 to 04:00 h had beneficial impacts on their performance. Finally, feeding growing rabbits during 22:00 to 04:00 as recommended in the hot summer.

Key words: Feeding time, growth performance, carcass characteristics, hot summer, rabbits.

Productive and health performance of rabbits are affected by several environmental and managerial impacts such as high air temperature, relative humidity, lighting, feeding, housing, overcrowding, handling and transportation ...etc (Mahrose et al., 2010; Farghly and Hamdon 2015, 2016 and 2017). High air temperature and relative humidity $(\%)$ are one of the major problems that confront rabbit producers in tropical and sub-tropical regions (Mahrose, 2000; Farghly, 2011; Hassan et al., 2016; Farghly and Hamdon 2017), where it influences rabbit performance (Marai et al., 2004; Farghly et al., 2016 and 2017).

Changing or restriction of feeding time in growing rabbits was studied in the last decades as a method to alleviate the deleterious influences of heat stress (Abdel-Monem et al., 2007; Mahrose et al., 2010 and Sena et al., 2012), to improve biological performance (Tůmová et al., 2006; Xiccato and Trocino, 2010 and Farghly et al., 2017) and can avoid feed losses. Feeding planning in growing rabbits should be applied to get the highest weights at marketing and the lowest feed conversion (Farghly and Abdelnabi, 2014; Sena et al., 2012 and 2015). Feeding behavior can be influenced by diurnal rhythms (Ojebiyi et al., 2015).

Rabbits consume feed at any time in the day, though they prefer to feed nocturnally (Abd El-Monem et al., 2007 and Farghly and Abd El-Ati, 2011). Rabbits consume $60-70 \%$ of the feed at night, before dawn and after dusk (Schlolaut, 1984, Gidenne et al., 2010 and Ojebiyi et al., 2015). The feeding habits of the wild rabbits are even more nocturnal than those of domesticated 
rabbits (Lebas et al., 1986). Although, there are three top intervals of feed intake a day in the rabbits; these are during 3:00-06:00, 15:00-18:00 and 18:0021:00 h (Ogbu et al., 2014).

Restricting the feeding time could be a suitable method for reducing feed intake and improving feed conversion (Matics et al., 2012 and Uhliřoval et al., 2015).When restricted feeding time is applied, there may be raise in feed efficiency (Tůmová et al., 2003 and 2006; Dalle-Zotte et al., 2005 and de Oliveira et al., 2012), compensatory growth (Gidenne et al., 2012) and carcass characteristics should be consider (reducing fat deposition) when estimating alternative feeding programs (Yakubu et al., 2007; de Oliveira et al., 2012 and Chodová et al., 2017). As well as, feeding time of the day influences certain behaviors as feeding, the total activity in rabbits (Ogbu et al., 2014), the biochemical parameters (Chodová and Tůmová, 2013 and Chodová et al., 2017) and can be a prohibition against digestive-disorders (Tůmová et al., 2006). The effect of feed restriction relies on the duration of restriction, its intensity and the time of application (Chodová and Tůmová, 2013).

Therefore, the present work was designed to determine the effects of changing feed restriction time on growth performance, carcass characteristics, blood biochemical parameters and some health aspects during the summer season under conditions of Assiut Governorate, Egypt.

\section{MATERIALS AND METHODS}

The present experiment was carried out at the Research Poultry Farm of Poultry Production Department, Faculty of Agriculture, Assiut University, Assiut, Egypt. The work lasted for 10 weeks in summer season (July to August), where the environmental temperature ranged between $25.6^{\circ} \mathrm{C}$ to 36.4 ${ }^{\circ} \mathrm{C}$ while, relative humidity (\%) was from 40.4 to $61.4 \%$.Values of the ambient temperature, relative humidity and temperature-humidity index (THI) are presented in Table 1. Values of THI were calculated according to the formula of Marai et al. (2001) as follows:

$$
\mathrm{THI}=\mathrm{db} \mathrm{C}^{o}-\left\{(0.31-0.31 \mathrm{RH})\left(\mathrm{db} \mathrm{C}^{o}-14\right)\right\} \text {, }
$$

Where $\mathrm{db} \mathrm{C}^{o}=$ dry bulb temperature in Celsius and $\mathrm{RH}=\mathrm{RH} \% / 100$. The estimated values of THI were classified as follows: $<22.2=$ Absence of heat stress, $22.2-<23.2=$ Moderate heat stress, $23.3-<25.5=$ Severe heat stress and 25.5 and more $=$ very severe heat stress.

\section{Experimental animals and design:}


Sixty-five of growing male New Zealand White (NZW) rabbits, six weeks old, were randomly divided into five experimental groups (13 rabbits per each). In the control group (C), the feed was offered ad libitum daily.

Table 1. Means of indoor air temperature and humidity values, during summer season

\begin{tabular}{cccccccccc}
\hline \multirow{2}{*}{$\begin{array}{c}\text { Intervals } \\
\text { (month) }\end{array}$} & \multicolumn{3}{c}{ Temperature $\left(\mathbf{C}^{\circ}\right)$} & \multicolumn{3}{c}{ Humidity $(\boldsymbol{\%})$} & \multicolumn{3}{c}{ THI } \\
\cline { 2 - 9 } Max. & Min & Av. & Max. & Min. & Av. & Max. & Min. & Av. \\
\hline June & 33.88 & 24.64 & 29.26 & 59.85 & 42.23 & 51.04 & 31.46 & 22.81 & 27.00 \\
July & 35.00 & 27.11 & 31.06 & 62.00 & 44.52 & 53.26 & 32.57 & 24.92 & 28.64 \\
August & 35.92 & 26.86 & 31.39 & 61.22 & 43.00 & 52.11 & 33.33 & 24.66 & 28.87 \\
\hline Overall mean & $\mathbf{3 4 . 9 3}$ & $\mathbf{2 6 . 2 0}$ & $\mathbf{3 0 . 5 7}$ & $\mathbf{6 1 . 0 2}$ & $\mathbf{4 3 . 2 5}$ & $\mathbf{5 2 . 1 4}$ & $\mathbf{3 2 . 4 5}$ & $\mathbf{2 4 . 1 3}$ & $\mathbf{2 8 . 1 7}$ \\
\hline Max = Maximum, Min= Minimum, Av. = average and THI = Temperature-humidity index.
\end{tabular}

While, in the first treated group (T1), rabbits were fed during10:00 and 16:00 $\mathrm{h}$. The second group (T2) was fed during 16:00 to 22:00 h. The third treatment group (T3) was fed during 22:00 to 04:00 h. The fourth treatment group (T4) was fed at 04:00 to10:00 h, throughout the experimental period from 6 to 16 weeks of age.

Light intensity measured at the middle of the cages ranged between 25-30 lux. using incandescent bulbs in semi-closed house. Rabbits were ear tagged housed in a wire galvanized battery cages $(50 \mathrm{~L} \times 55 \mathrm{~W} \times 40 \mathrm{H} \mathrm{cm})$, which supplied with feeders and automatic nipple drinkers. Rabbits were fed basal diet contained $2670 \mathrm{ME} / \mathrm{kcal}, 18.25 \% \mathrm{CP}$ and $11.17 \% \mathrm{CF}$ (weaning and up to marketing age) according to NRC (1977). Rabbits were reared under the same managerial, feeding and hygienic conditions throughout the experimental period.

\section{Investigated measurements:}

Exterior and interior temperature $\left({ }^{\circ} \mathrm{C}\right)$ and relative humidity $(\%)$ were measured by using a thermo hygrograph allover the experimental period. The daily and periodical (4weeks) averages environmental temperature and RH were recorded (Table 1).

\section{Studied parameters:}

Weaned rabbits were weighed at the beginning of the experiment ( 6 weeks of age) and every two weeks thereafter up to 16 weeks on individual basis to the nearest gram. Feed intake (FI) was recorded individually at 14-d intervals to be used in calculating feed conversion ratio (FCR) at intervals of 6-8, 8-10, 10-12, 12-14 and 14-16 weeks of age. Feed conversion ratio (FCR) was calculated as feed consumed divided by weight gain. Rectal temperature $\left({ }^{\circ} \mathrm{C}\right)$ was measured by using a thermometer inserted into the rectum for 2 
minutes at depth of $2 \mathrm{~cm}$ in midday (14:00h). Dead rabbits were recorded daily and expressed as percentage during the experimental period.

At the end of the experiment (16 weeks of age), 4 rabbits per group was randomly chosen and slaughtered. Carcass weight was considered as the weight of fore part, intermediate part and hind part. The weight of additional edible parts included the weight of the liver, heart and kidneys as giblet weight.

At slaughter, 6 blood samples were taken in two tubes, one contained EDTA and the other had no anticoagulant. Plasma was separated by centrifugation at $3000 \mathrm{rpm}$ for 20 minutes and kept in a deep freezer at -20 $\mathrm{C}$ until the time of analysis. Plasma total protein, albumin, globulin, albumin: globulin ratio, cholesterol, total lipids, glucose, cortisol, AST and ALT were determined by enzymatic method using available commercial kits. Globulin was calculated by subtraction of Plasma albumin from total plasma protein. Morbidity corresponded to frequency of enteric disease or severe loss of weight. Health risk was the sum of morbidity and mortality.

\section{Statistical analysis:}

Data collected were subjected to ANOVA by applying the General Linear Models Procedure of SAS software (SAS institute, version 6.12, 1996). The following model according to Snedecor and Cochran (1982) was used for analysis of variance:

$$
\mathrm{Y}_{\mathrm{ij}}=\mu+\mathrm{T}_{\mathrm{i}}+\mathrm{e}_{\mathrm{ij}}
$$

Where: $\mathrm{Y}_{\mathrm{ij}}=$ observation, $\mu=$ Overall mean, $\mathrm{T}_{\mathrm{i}}=$ Treatment effect $(\mathrm{i}=1$, $2 \ldots .5), \mathrm{e}_{\mathrm{ij}}=$ Experimental errors. The individual rabbit was the experimental unit in the present study.

Duncan (1955) was used to detect differences among means of different groups.

\section{RESULTS AND DISCUSION}

\section{Growth performance:}

There were significant $(\mathrm{P}<0.05)$ differences in body weight (at 12,14 and 16 weeks of age), body weight gain (during 14-16 and 6-16 weeks of age), feed intake (during 14-16 weeks of age) and feed conversion ratio (during 14-16 and 6-16 weeks of age) among all groups (Table 2).

The rabbits belonging to $\mathrm{T} 3$ group had the greatest averages and the lowest feed conversion ratio when compared with the other groups. In the current work, there are appropriate impacts on growth performance attributed to changing feeding times. During the coolest intervals of the day 
of the summer season, growing rabbits utilize the feed which within their normal natural feeding system (Ojebiyi et al.,2015). The same authors added that the number of feeds during light period drops and the morning "feeding rest ${ }^{\text {ee }}$ tends to lengthen.

Table 2. Effect of feeding times on growth performance of New Zealand White growing rabbits.

\begin{tabular}{|c|c|c|c|c|c|c|c|c|}
\hline \multirow{2}{*}{ Traits } & \multirow{2}{*}{$\begin{array}{c}\text { Age } \\
(\mathbf{w k s})\end{array}$} & \multicolumn{5}{|c|}{ Treatment groups } & \multirow{2}{*}{ SEM } & \multirow{2}{*}{$P$ value } \\
\hline & & $\mathbf{C}$ & T1 & $\mathbf{T 2}$ & T3 & T4 & & \\
\hline \multirow{6}{*}{$\begin{array}{c}\text { Body } \\
\text { weight } \\
\text { (g) }\end{array}$} & 6 & 742.61 & 743.52 & 727.36 & 734.73 & 726.00 & 5.12 & 0.8736 \\
\hline & 8 & 982.45 & 979.33 & 983.90 & 984.00 & 990.12 & 7.13 & 0.7925 \\
\hline & 10 & 1275.82 & 1252.11 & 1258.00 & 1300.36 & 1280.03 & 9.75 & 0.6276 \\
\hline & 12 & $1718.12^{\mathrm{ab}}$ & $1636.46^{\mathrm{b}}$ & $1650.00^{\mathrm{b}}$ & $1780.62^{\mathrm{a}}$ & $1766.85^{\mathrm{a}}$ & 10.82 & 0.0320 \\
\hline & 14 & $2000.44^{\mathrm{ab}}$ & $1930.26^{\mathrm{b}}$ & $1940.50^{b}$ & $2048.54^{\mathrm{a}}$ & $2036.00^{\mathrm{a}}$ & 11.25 & 0.0164 \\
\hline & 16 & $2270.35^{b}$ & $2152.78^{\mathrm{d}}$ & $2200.22^{c}$ & $2370.80^{\mathrm{a}}$ & $2350.52^{a}$ & 14.06 & $<.0001$ \\
\hline \multirow{6}{*}{$\begin{array}{l}\text { Body } \\
\text { weight } \\
\text { gain } \\
\text { (g/rabbi } \\
\text { t/day) }\end{array}$} & 6-8 & 17.13 & 16.84 & 18.32 & 17.81 & 18.87 & 0.35 & 0.6852 \\
\hline & 8-10 & 20.96 & 19.48 & 19.58 & 22.60 & 20.71 & 0.46 & 0.7931 \\
\hline & $10-12$ & 31.59 & 27.45 & 28.00 & 34.30 & 34.77 & 0.49 & 0.6262 \\
\hline & $12-14$ & 20.17 & 20.99 & 20.75 & 19.14 & 19.23 & 0.53 & 0.1416 \\
\hline & $\underline{14-16}$ & $19.28^{\mathrm{b}}$ & $15.89^{c}$ & $18.55^{\mathrm{b}}$ & $23.02^{\mathrm{a}}$ & $22.47^{\mathrm{a}}$ & 0.56 & 0.0003 \\
\hline & $6-16$ & $21.82^{a b}$ & $20.13^{b}$ & $21.04^{b}$ & $23.37^{\mathrm{a}}$ & $23.21^{a}$ & 0.17 & $<.0001$ \\
\hline \multirow{6}{*}{$\begin{array}{c}\text { Feed } \\
\text { intake } \\
\text { (g/rabbi } \\
\text { t/day) }\end{array}$} & $6-8$ & 61.00 & 59.22 & 60.15 & 60.86 & 60.88 & 0.26 & 0.8453 \\
\hline & $8-10$ & 70.42 & 67.00 & 67.56 & 68.75 & 69.00 & 0.46 & 0.4213 \\
\hline & $10-12$ & 93.26 & 89.06 & 90.11 & 91.54 & 91.82 & 0.56 & 0.3562 \\
\hline & $12-14$ & 102.32 & 99.89 & 100.34 & 101.36 & 101.13 & 0.64 & 0.7343 \\
\hline & $\underline{14-16}$ & $110.00^{\mathrm{a}}$ & $103.30^{b}$ & $104.71^{b}$ & $108.42^{\mathrm{ab}}$ & $108.10^{\mathrm{ab}}$ & 0.60 & 0.0195 \\
\hline & $6-16$ & 87.40 & 83.69 & 84.57 & 86.18 & 86.19 & 0.43 & 0.7462 \\
\hline \multirow{6}{*}{$\begin{array}{c}\text { Feed } \\
\text { convers } \\
\text { ion } \\
(\mathrm{g} \\
\text { feed/g } \\
\text { gain) }\end{array}$} & $6-8$ & 3.56 & 3.52 & 3.28 & 3.42 & 3.23 & 0.09 & 0.6524 \\
\hline & 8-10 & 3.36 & 3.44 & 3.45 & 3.04 & 3.33 & 0.10 & 0.7423 \\
\hline & $10-12$ & $2.95^{\mathrm{ab}}$ & $3.24^{\mathrm{a}}$ & $3.22^{\mathrm{a}}$ & $2.67^{b}$ & $2.64^{b}$ & 0.07 & 0.0340 \\
\hline & $12-14$ & 5.07 & 4.76 & 4.84 & 5.30 & 5.26 & 0.12 & 0.8441 \\
\hline & $14-16$ & $5.71^{\mathrm{ab}}$ & $6.50^{\mathrm{a}}$ & $5.64^{\mathrm{ab}}$ & $4.71^{\mathrm{b}}$ & $4.81^{\mathrm{b}}$ & 0.19 & 0.0226 \\
\hline & $6-16$ & $4.00^{a b}$ & $4.16^{a}$ & $4.02^{a b}$ & $3.69^{b}$ & $3.71^{b}$ & 0.04 & 0.0138 \\
\hline
\end{tabular}

a-d Means within each row for each division with no common superscripts are significantly different $(\mathrm{P} \leq 0.05)$.

During the night, there is an elevation in activity, reduction in stress and boredom unlike the experience during the rest of the day. The reduction in feed intake is the main sign of heat exposure (Abdel-Monem et al., 2007) 
and such reduction in feed intake during the hottest intervals of the day may due to the environmental temperature, which stimulates peripheral thermal receptors to transmit suppressive nerve impulses to the appetite center in the hypothalamus resulting in a reduction in feed intake.

Restricting feeding times enhancing feed utilization (Dalle- Zotte et al., 2005). Ogbu et al. (2014) who found that rabbits consume the most of their feed during 03:00-06:00, 15:00-18:00 and 18:21 h. Bergaoui et al. (2008) showed that the diet was eaten through 16:00 $\mathrm{h}$ for an 85\% FI and during 10:00 $\mathrm{h}$ for a $70 \% \mathrm{FC}$ during summer season. Feeding time restriction to 7:00 $\mathrm{h}$ a day did not significantly affect growth performance of growing rabbits (Sena et al., 2012). Feeding growing rabbits for only $10 \mathrm{~h}$ a day decreased FI by $20 \%$, while night feeding decreased FI by $10 \%$ and the daily gain to 5\% (Sena et al., 2015). Osman (1991) and Tůmová et al. (2003) indicated that feeding growing rabbits 7:00 h per day did not impact body weight at marketing age. The current results are in agreement with those reported by Mahrose (2000), Bovera et al. (2008), Ojebiyi et al. (2015) and Farghly et al. (2017) who observed that BW of rabbits on night feeding exceeded those of the day feeding. However, Tůmová et al. (2003), Yakubu et al. (2007), Matics et al. (2012), Duperray et al. (2012) and Uhliřoval et al. (2015) observed non-significant changes in final body weight of growing rabbits due to feeding times.

\section{Carcass characteristics:}

Data presented in Table 3 indicated that the rabbits fed during 22:00 to 04:00 $\mathrm{h}(\mathrm{T} 3)$ showed significantly $(\mathrm{P}<0.05)$ the highest percentages of dressed carcass as compared with their counter parts. However, rabbits of the control group gave significantly $(\mathrm{P}<0.05)$ the lowest average of whole fat percentage in comparison with the other groups. Non-significant differences were found in the other carcass characteristics due to changing feeding time. Carcass characteristics are the most important elements to take into consideration when assessing alternative feeding programs (Tůmová et al., 2006).

Contradictory findings in results of carcass characteristics could be caused by different intensities and times of feed restriction or changing. The current results are in line with those observed by Tůmová et al. (2003), Yakubu et al. (2007), Duperray et al. (2012), Ojebiyi et al. (2015) and Sena et al. (2015) who indicated non-significant differences in carcass characteristics due to feeding times. On the other hand, Matics et al. (2012) 
Table 3. Effect of feeding times on carcass traits of New Zealand White growing rabbits.

\begin{tabular}{|c|c|c|c|c|c|c|c|}
\hline \multirow{2}{*}{ Traits } & \multicolumn{5}{|c|}{ Treatment groups } & \multirow{2}{*}{ SEM } & \multirow{2}{*}{$\begin{array}{c}\mathbf{P} \\
\text { value }\end{array}$} \\
\hline & $\mathbf{C}$ & T1 & $\mathbf{T 2}$ & T3 & T4 & & \\
\hline Heart, \% & 0.433 & 0.407 & 0.416 & 0.424 & 0.419 & 0.002 & 0.7265 \\
\hline Liver, \% & 4.92 & 3.81 & 3.90 & 4.65 & 4.45 & 0.058 & 0.1658 \\
\hline Kidney, \% & 0.745 & 0.688 & 0.711 & 0.732 & 0.694 & 0.092 & 0.4768 \\
\hline Whole fat, \% & $3.16^{\mathrm{a}}$ & $2.53^{\mathrm{b}}$ & $2.98^{\mathrm{ab}}$ & $3.03^{\mathrm{ab}}$ & $3.04^{\mathrm{ab}}$ & 0.091 & 0.0235 \\
\hline Dressed,\% & $58.71^{\mathrm{ab}}$ & $57.12^{\mathrm{b}}$ & $58.38^{\mathrm{ab}}$ & $59.11^{\mathrm{a}}$ & $58.62^{\mathrm{ab}}$ & 0.523 & 0.0437 \\
\hline
\end{tabular}

reported that rabbits fed ad libitum had significantly higher dressing percentage than those of the restricted groups.

\section{Blood constituents:}

Results of the effect of feeding times on blood constituents (Within normal range according to Stevin (1974) ) are presented in Table 4. Rabbits of T3 group showed the lowest $(\mathrm{P}<0.05)$ values of $\mathrm{A} / \mathrm{G}$ ratio and neutrophil/ lymphocytes (N/L) ratio when compared with their counterparts. Glucose concentration was high $(\mathrm{P}<0.05)$ in plasma of rabbits of the control group and those fed during 2200 to $0400 \mathrm{~h}$ (T3). Blood constituents in rabbits are as indicators of stress conditions and evaluation of the metabolic processes and the health status (Chodová et al., 2017). Diurnal and seasonal variations are among the most important factors affecting blood constituents (Çetin et al., 2009).Total plasma concentrations of protein, globulin and albumin are related to its metabolism and were within the normal physiological range mentioned by (Özkan et al., 2012). The present findings confirmed that restricting and changing feeding times did not impact the synthesis and transfer of plasma proteins and protein catabolism (Chodová et al., 2017).

Glucose concentrations significantly influenced by changing feeding times and that was in line with the findings of Rommers et al. (2004), while it was on contrary to what is reported by Van Harten and Cardoso (2010) and ElSpeiy et al. (2015). Most of our results were not impacted by changing feeding times which corresponds with Mahrose (2000), Abdel-Monem et al. (2007), Mahrose et al. (2010), Chodová et al. (2017). The present findings disagree with those showed by Mahrose (2000), Attia(2004) and Azoz and El-Kholy (2006) who obtained significant differences in the present blood components due to season effects. 
Table 4. Effect of feeding times on blood constituents of New Zealand White growing rabbits.

\begin{tabular}{|c|c|c|c|c|c|c|c|}
\hline \multirow{2}{*}{ Traits } & \multicolumn{5}{|c|}{ Treatment groups } & \multirow{2}{*}{ SEM } & \multirow{2}{*}{$P$ value } \\
\hline & $\mathbf{C}$ & $\mathbf{T 1}$ & T2 & T3 & T4 & & \\
\hline $\begin{array}{l}\text { Total proteins } \\
(\mathbf{m g} / \mathbf{d l})\end{array}$ & 7.33 & 6.85 & 6.91 & 7.14 & 7.19 & 0.09 & 0.7562 \\
\hline Globulin (mg/dl & 3.15 & 2.76 & 2.85 & 3.11 & 3.10 & 0.06 & 0.8648 \\
\hline Albumin (mg/dl & 4.18 & 4.09 & 4.06 & 4.03 & 4.09 & 0.04 & 0.3496 \\
\hline A:G ratio & $1.33^{\mathrm{b}}$ & $1.48^{\mathrm{a}}$ & $1.42^{\mathrm{ab}}$ & $1.30^{\mathrm{b}}$ & $1.32^{\mathrm{b}}$ & 0.03 & 0.0324 \\
\hline $\begin{array}{l}\text { Total lipids } \\
\text { (g/dl) }\end{array}$ & 3.13 & 2.88 & 2.92 & 3.04 & 3.02 & 0.05 & 0.6275 \\
\hline Glucose (mg/dl) & $17.00^{\mathrm{a}}$ & $13.89^{b}$ & $13.93^{\mathrm{b}}$ & $16.91^{\mathrm{a}}$ & $16.06^{\mathrm{ab}}$ & 0.56 & 0.0426 \\
\hline AST U/I & 31.71 & 32.78 & 31.32 & 29.81 & 30.63 & 0.89 & 0.4276 \\
\hline ALT U/I & 18.11 & 18.55 & 18.39 & 16.79 & 17.00 & 0.41 & 0.2625 \\
\hline N / L Ratio & $0.58^{\mathrm{a}}$ & $0.59^{\mathrm{a}}$ & $0.54^{\mathrm{ab}}$ & $0.47^{\mathrm{c}}$ & $0.49^{\mathrm{bc}}$ & 0.01 & 0.0026 \\
\hline Cortisol (ng/ml) & 12.93 & 13.11 & 11.80 & 10.73 & 11.00 & 1.11 & 0.4283 \\
\hline
\end{tabular}

\section{Health aspects:}

Body temperature of rabbits fed during 22:00 to 04:00 $\mathrm{h}$ had the lowest temperature as compared with the other groups (Table 5). There were non-significant differences in morbidity, mortality and health risk percentages. Our strategy of changing feeding times improved the health aspects of rabbits under heat stress conditions compared to the ad libitum group. This suggests that under heat stress conditions, the restriction and changing feeding times that induce the improvement of health. The improvement in body temperature of rabbits fed during 22:00 to 04:00 $\mathrm{h}$ in the present study might be attributed to the improvement in environmental conditions during that time. During heat stress conditions, mortality rate (\%) is the most obvious indicator (Bovera et al., 2008). Feed restriction has positive influence on the health status of growing rabbits after weaning (Chodová and Tůmová, 2013).

In that respect, Abdel-Monem et al. (2007) and Ojebiyi et al. (2015) showed that rectum temperature was insignificantly influenced by feeding times. Peter (1999) confirmed that at normal rectal temperature (comfort temperature); rabbits ingest approximately $200 \%$ as much water as feed.

This applies to the rabbits fed exclusively at the period of 22:00 to 04:00 h, but got only water during the rest of the day. The reduction in body 
Table 5. Effect of feeding times on rectal temperature and healthy aspects of New Zealand White growing rabbits.

\begin{tabular}{|c|c|c|c|c|c|c|c|}
\hline \multirow{2}{*}{ Traits } & \multicolumn{5}{|c|}{ Treatment groups } & \multirow{2}{*}{ SEM } & \multirow{2}{*}{$\begin{array}{c}P \\
\text { value }\end{array}$} \\
\hline & $\mathbf{C}$ & T1 & $\mathbf{T 2}$ & T3 & T4 & & \\
\hline Rectal temperature $\left(\mathrm{C}^{\circ}\right)$ & $40.36^{\mathrm{ab}}$ & $40.71^{\mathrm{a}}$ & $40.29^{\mathrm{ab}}$ & $39.53^{\mathrm{b}}$ & $39.58^{\mathrm{b}}$ & 0.08 & 0.0425 \\
\hline Morbidity, \% & 12.50 & 12.50 & 12.50 & 0.00 & 0.00 & 1.76 & 0.3562 \\
\hline Mortality, \% & 0.00 & 25.00 & 12.50 & 12.50 & 0.00 & 1.91 & 0.4892 \\
\hline Health risk, \% & 12.50 & 37.50 & 25.00 & 12.50 & 0.00 & 2.06 & 0.6396 \\
\hline
\end{tabular}

$\mathrm{a}$ and $\mathrm{b}$ Means within each row for each division with no common superscripts are significantly different $(\mathrm{P} \leq 0.05)$.

temperature of rabbits fed during 22:00 to 04:00 $\mathrm{h}$ in comparison with the other rabbits may help in enhancing feed intake and body weight of those rabbits. However, Tůmová et al., (2003), Bergaoui et al., (2008), Matics et al., (2012) and Duperray et al., (2012) concluded that feed restriction did not significantly affected mortality and health status of the growing rabbits. Bovera et al., (2008) found that mortality rate (\%) was significantly higher for restricted group than the control one due to heat stress.

Conclusively, it could be concluded from the present results, that changing feeding time in growing rabbits during 22:00 to 04:00 h. Finally, feeding growing rabbits during 2200 to 0400 as recommended had beneficial impacts on their growth performance.

\section{REFERENCES}

Abdel-Monem, U.M.; Khalil, B.A. and Mahrose, Kh.M. (2007). Effects of feeding times on performance of New Zealand White rabbit does. The $5^{\text {th }}$ International Congress of Rabbit Production under hot climates. Hurghada, Egypt, December $4-7$.

Attia, I. E. I. (2004). Effect of some factors on physiological and productive process of rabbits. M. Sci. Thesis, Fac. Agric., Zagazig Univ., Egypt.

Azoz, A. A. and El-Kholy, K. H. (2006).Reproductive performance and blood constituents of $\mathrm{V}$-line and Bouscat female rabbits under middle Egypt conditions. Egypt. J. Rabbit Sci., 16 (1): $139-160$.

Bergaoui, R.; Kammoun, M. and Ouerdiane, K. (2008).Effects of feed restriction on the performance and carcass of growing rabbits. Proceedings of the $9^{\text {th }}$ World Rabbit Congress, June 10-13, Verona, Italy, pp. 547-550. 
Bovera, F.; Di Meo, C.; Marono, S.; Vella, N. and Nizza, A. (2008). Feed restriction during summer: effect on rabbit growth performance. $9^{\text {th }}$ World Rabbit Congress, June 10-13, 2008, Verona, Italy, pp: 567-571.

Çetin, N.;Bekyürek, T. andÇetin T.(2009). Effects of sex, pregnancy and season on some haematological and biochemical blood values in Angora rabbits. Scandinavian Journal of Laboratory Animal Science, 36: 155-162.

Chodová, D. and Tůmová, E. (2013). The effect of feed restriction on meat quality of broiler rabbits: A review. Scientia AgriculturaeBohemica, 44 (1): 55-62.

Chodová, D.; Tůmová, E.; Härtlová, H.; Fučíková,A.; Volek, Z. and Vlčková, J. (2017).Changes of haematological and biochemical indices with age in rabbits with ad libitum and limited feed intake. Acta Vet Brno, 86: 29-35.

Dalle-Zotte, A.; Rémignon, H.; Ouhayoun, J. (2005). Effect of feed rationing during post-weaning growth on meat quality, muscle energy metabolism and fibre properties of Biceps femoris muscle in the rabbit. Meat Science, 70: 301-306.

de Oliveira, M.C.; da Silva, R.P.; Araújo, L.S.; da Silva, V.R.; Bento, E.A. and da Silva, D.M. (2012). Effect of feed restriction on performance of growing rabbits. Revista Brasileira de Zootecnia, 41: 1463-1467.

Duncan, D. B. (1955).Multiple ranges and multiple F-tests. Biometrics, 11, 1-42.

Duperray, J.; Laurent, J.M.; Adelis, R.; Haberkorn, F. and Guyonvarch, A. (2012). Time feed restriction reduces digestive disorders without decreasing growth performances of growing rabbits in ERE conditions. Proceedings of the $10^{\text {th }}$ World Rabbit Congress, September 3 - 6, Sharm El-Sheikh, Egypt, pp: 663 - 668.

El-Speiy, M. E.; Kamel, K.I.; Tag El-Din, A. E.; Abd El-Hamid, A. E. and El-Kamhawey, A.M. (2015). Effect of feed restriction on productive performance, carcass yield, blood pictures and relative organ weights of growing rabbits. Egyptian Poultry Science Journal, 35 (II): 439-454.

Farghly M. F. A., (2011). Using light flashes programme as a tool to avoid the hot weather effect on growth performance of New Zealand White rabbits. Egypt. Poultry Sci., 31:437-451.

Farghly, M.F.A. and Hamdon, H. (2015). Evaluating intermittent flashed light as economical light source for raising New Zealand white rabbits. Egyptian Journal of Rabbit Science, 25: 21 - 38. 
Farghly M. F. A. and H. Hamdon (2016). Suitable housing type of growing New Zealand White rabbits under hot conditions of Upper Egypt. Egyptian Journal of Rabbit Science, 26(1): 21 - 38.

Farghly M. F. A. and H. Hamdon (2017). Applying cold water in managing New Zealand Rabbits in hot climate. The $8^{\text {th }}$ International Rabbit Production In Hot Climates Conference, 8 - 11 March 2017, Hurghada, Red Sea, Egypt, (abstract).

Farghly M. F. A. and M. N. Abd El-Ati, (2011). Effect of light flashes on growth performance, carcass characteristics and chemical composition of meat in New Zealand white rabbits. Egyptian J. Anim. Prod. 48:55-67.

Farghly M. F. A. and M. A. Abdelnabi, (2014). Effect of light flashes on reproductive performance of New Zealand white rabbits (Abstract). 7th International Poultry Conference, 3 - 6 November 2014, Ain Soukhna, Red Sea, Egypt.

Farghly, M.F.A.; Abdelnabi, M.A. and Hamdon, H. (2016). Effect of intermittent light flashes on reproductive performance of New Zealand White rabbits. $3^{\text {rd }}$ International Conference on Agricultural Biotechnology Applications, April 5-9, 2016, Moshtohor and Sharm El-Sheikh, Egypt (Abstract).

Farghly, M. F. A.; Mahmoud, G. B. and Mahrose, Kh. M. (2017).Using light: dark time and period to alleviate the heat stress on growing New Zealand White rabbits during hot weather. The $8^{\text {th }}$ International Conference on Rabbit Production in Hot Climates, 8-11 March, Hurghada, Egypt (Abstract).

Gidenne, T. and Lebas, F. and Fortun-Lamothe, L. (2010).Feeding behaviour in rabbits.In: de Blas C., Wiseman J., "Nutrition of the rabbit" - 2010 - CAB International Ed., pp: 233-252.

Gidenne, T.; Combs, S. and Fortun-Lamothe, L. (2012). Feed intake limitation strategies for the growing rabbit: effect on feeding behaviour, welfare, performance, digestive physiology and health: a review. Animal, 6: 1407-1419.

Hassan, F.A.; Mahrose, Kh.M. and Basyony, M.M. (2016). Effects of grape seed extract as a natural antioxidant on growth performance, carcass characteristics and antioxidant status of rabbits during heat stress. Archives of Animal Nutrition, 70: 141-154.

Lebas, F.; Coudert, P.; Rouvier, R. and Rochambeau, H. (1986). The rabbit; husbandry, health and production. FAO Animal Production and Health Series, No 21. 
Mahrose, Kh.M. (2000). Environmental studies on growth and reproduction traits in rabbits. M.Sc. Thesis, Faculty of Agriculture, Zagazig University, Egypt.

Mahrose, Kh. M.; Abd El-Monem, U.M. and Peris, S.I. (2010). Effects of photoperiod and mating or semen collection times on the performance of does and bucks of New Zealand White rabbits under hot climatic conditions of Egypt. In The $6^{\text {th }}$ International Conference on Rabbit Production in Hot Climates, pp. 503-520.February 1-4, Assuit, Egypt.

Marai, I. F. M.; Ayyat, M. S. and Abd El-Monem. U. M. (2001). Growth performance and reproductive traits at first parity of New Zealand White female rabbits as affected by heat stress and its alleviation under Egyptian conditions. Journal of Tropic. Anim. Health and Production, 33: 1 - 12.

Marai, I.F.M.; Haeeb A.A. and Gad, A.E. (2004). Growth performance traits and the physiological background of young doe rabbits as affected by climatic conditions and lighting regime, under sub-tropical conditions of Egypt. Proceedings - $8^{\text {th }}$ World Rabbit Congress September 7-10, 2004 - Puebla, Mexico, pp; 288-297.

Matics, Zs.; Dalle-Zotte, A.; Radnai, I.; Kovács, M.; Metzger, Sz. and Szendrö, Zs. (2012). Effect of restricted feeding after weaning on the productive and carcass traits of growing rabbits. Proceedings of The $10^{\text {th }}$ World Rabbit Congress, September 3 - 6, Sharm El-Sheikh, Egypt, $741-745$.

NRC (1977). Nutrient Requirements of Poultry. $9^{\text {th }}$ revised ed. National Research Council, National Academy Press, Washington, D.C., USA.

Ogbu, C.C.; Ani, A.O. and Nwogwugwu, P. (2014). Growth performance, feed preference and circadian variation in behavioural traits of rabbits reared singly and in group. Jour. of Anim. Prod. Advances, 4: 488-500.

Ojebiyi, O.O.; Olarinde, O.J.; Adepoju, A.A.; Akinola, A.O. and Adetutu, O.I. (2015). Performance of rabbits on exclusive day and/ or night feeding regime in the derived Savannah zone of Nigeria. Online Journal of Animal and Feed Research, 5: 45-49.

Osman, A. M. A.(1991).Effect of reducing feeding time on the growth performance, carcass traits and meat quality of growing rabbits. Arch. Geflu"gelkde., 55: 196-200.

Özkan, C.; Kaya, A. and Akgül, Y.(2012). Normal values of haematological and some biochemical parameters in serum and urine of New Zealand White rabbits. World Rabbit Science, 20: 253-259. 
Peter, P.H. (1999).Physiology of water and electrolyte balance. Poultry Journal, 38 (11): 54.

Rommers, J.M.; Boiti, C.; Brecchia, G.;Meijerhof, R.;Noordhuizen, J.P.T.M.;Decuypere, E. and Kemp, B.(2004). Metabolic adaptation and hormonal regulation in young rabbit does during long-term caloric restriction and subsequent compensatory growth. Anim. Sci., 79: 255-264.

SAS (1996). SAS Procedures Guide.Version 6.12 Edition. SAS Institute INC. Cary, NC, USA.

Schlolaut, W. (1984). The nutrition of the rabbit. Hoffman la Rocheco. AG, Basel, Switzerland, Pp:40.

Sena, L.; Sena, S. and Biçoku, Y. (2012).Effect of reduction of feeding time on the performance of growing rabbits. $3^{\text {rd }}$ International Scientific Symposium "Agrosym Jahorina, 2012", Faculty of Agriculture, University of East Sarajevo, Jahorina, Nov.15-17, 504-508.

Sena, S.; Sena, L.; Nikolova, N. and Biçoku, Y. (2015). The effect of restricted feeding for an extended period of time on the carcass`s fattening parameters of rabbits. Macedonian Journal of Animal Science, 5: 19-23.

Snedecor, G. W. and Cochran, W. G. (1982). Statistical Methods. $7^{\text {th }}$ Ed. Iowa State Univ. Press. Ames. Iowa.

Tůmová, E.; Skřivanová, V. and Skřivan, M. (2003). Effect of restricted feeding time and quantitative restriction in growing rabbits. Archivfür Geflügelkunde, 67: 182-190.

Tůmová, E.; Zita, L. and Štolc, L. (2006). Carcass quality in restricted and ad libitum fed rabbits. Czech Journal of Animal Science, 51: 214-219.

Uhliřoval, L.; Volek, Z.; Marounek, M. andTůmová, E. (2015). Effect of feed restriction and different crude protein sources on the performance, health status and carcass traits of growing rabbits. World Rabbit Science, 23: 263-272.

Van Harten, S. and Cardoso, L.A.(2010). Feed restriction and genetic selection on the expression and activity of metabolism regulatory enzymes in rabbits. Animal, 4: 1873-1883.

Xiccato, G. and Trocino, A. (2010). Feed and energy intake in rabbits and consequences on farm global efficiency. In: The $6^{\text {th }}$ International Conference on Rabbit Production in Hot Climates, pp. 503-520. February 1-4, Assuit, Egypt, pp: 1-18. 
Yakubu, A.; Salako, A.E.; Ladokun, A.Q.; Adua, M.M. and Bature, T.U.K. (2007). Effects of feed restriction on performance, carcass yield, relative organ weights and some linear body measurements of weaner rabbits. Pakistan Journal of Nutrition, 6: 391-396.

\section{تغيير وقت التغذية لتجنب التأثيرات الضارة للصيف الحار على أرانب النيوزلندي الأبيض النيران}

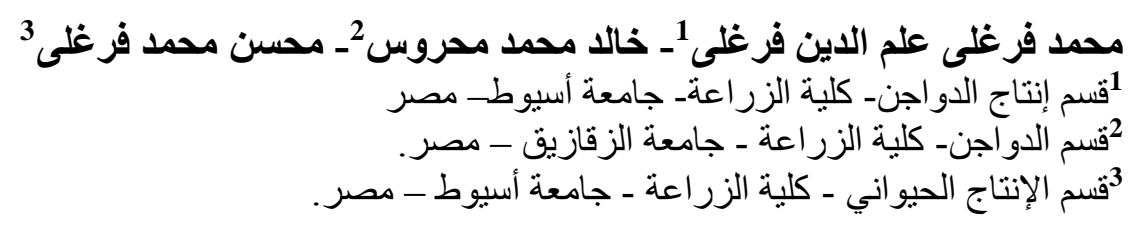

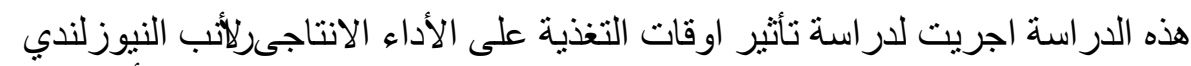

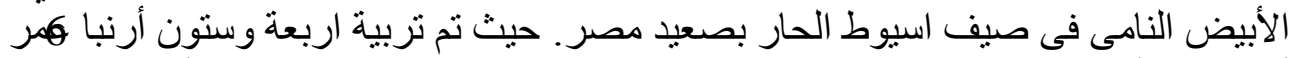

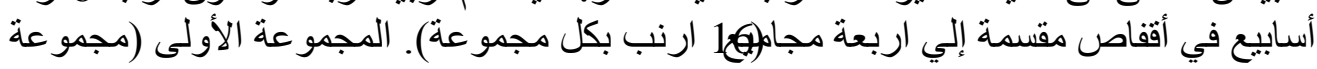

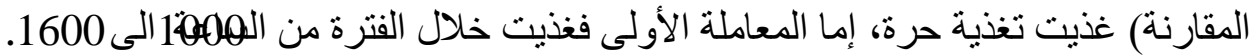

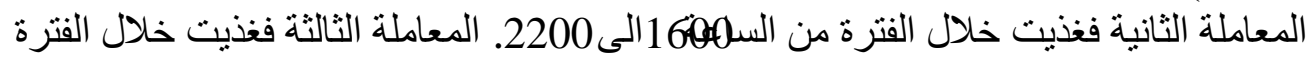

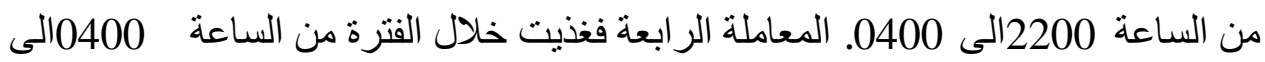

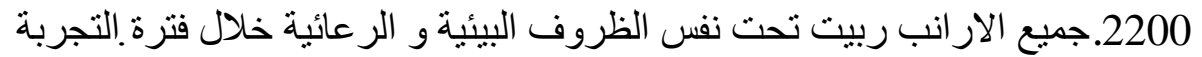

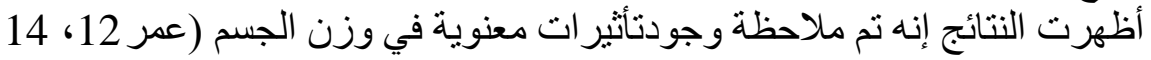

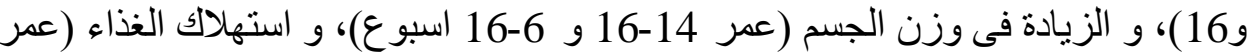

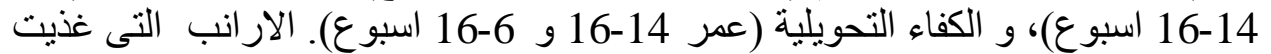

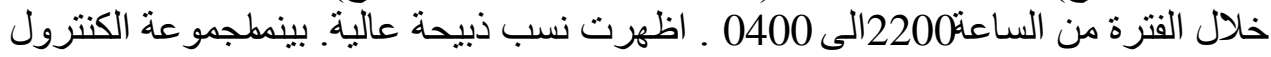

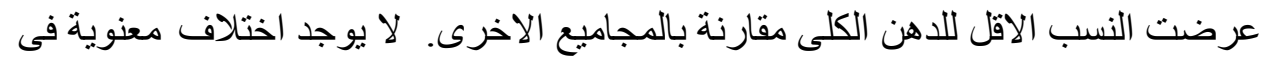

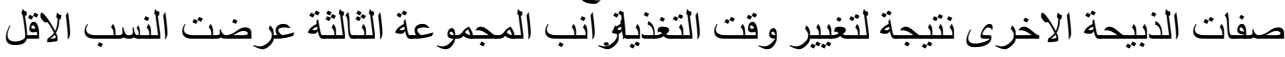
لـ الـ A/L ratio

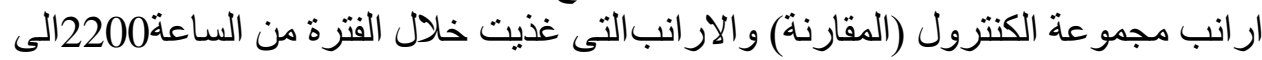

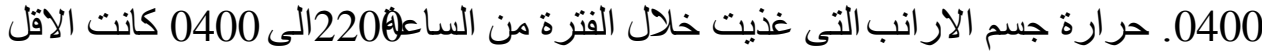

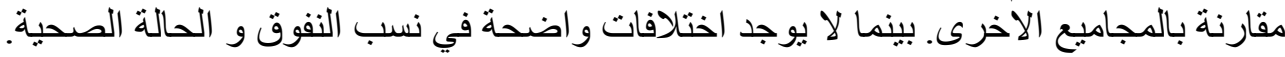

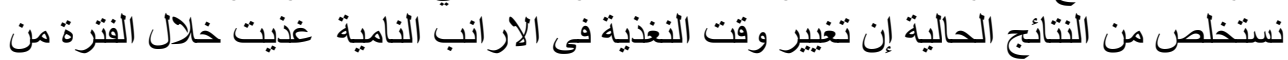

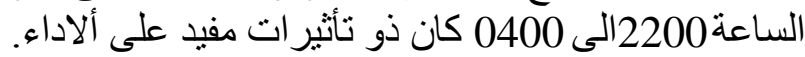

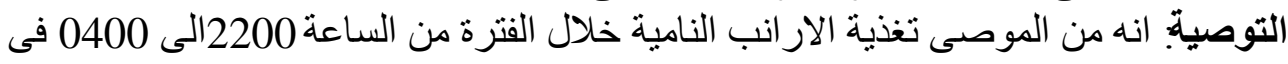

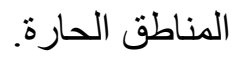

